\title{
CLAVES PARA LA LECTURA \\ DE ORATORIO DE SAN BERNARDINO, DE ALFONSA DE LA TORRE ${ }^{1}$
}

\author{
KEYS TO READING ORATORIO DE SAN BERNARDINO, \\ BY ALFONSA DE LA TORRE
}

María PAYERAS GRAU

Universitat de les Illes Balears

Resumen: En la obra poética de Alfonsa de la Torre, autora segoviana de la primera promoción poética de la posguerra actualmente en fase de recuperación, sobresale su libro Oratorio de San Bernardino (1950), un poemario que, a partir de un plano objetivo, como es la recreación ecfrástica del conjunto escultórico de la portada del Oratorio de los santos Andrea y Bernardino en Peruggia, obra renacentista de Agustino del Duccio, desarrolla un discurso subjetivo y autoindagatorio. El poemario amalgama el carácter culturalista de sus motivos con una temática de inspiración religiosa a la que sobrepone componentes transgresores respecto a la moral dominante

Palabras clave: Poesía de posguerra. Feminismo. Écfrasis. Simbología. Liturgia y cultura católicas.

1. Este artículo se halla vinculado al Proyecto de Investigación del Plan Estatal "Poéticas del 50: proyecciones y diversificaciones", ref. FFI2013-41321-P (AEI/FEDER, UE). 
Abstract: From the poetry written by Alfonsa de la Torre - a Segovian author part of the first wave of Spanish postwar poets whose work is currently being recovered-, her book Oratorio de San Bernardino (1950) stands out particularly. In it, the author develops a subjective and selfenquiring discourse from an objective plane such as is the ekphrastic recreation of the sculptural body of the Oratory of Saints Andrea and Bernardino's façade in Peruggia, which is the work of Renaissance artist Agostino di Duccio. Alfonsa de la Torre's book of poems combines erudite motifs which themes of Catholic inspiration to which elements transgressive of the dominant morals of the time are superposed.

Key Words: Postwar poetry. Feminism. Ekphrasis. Symbology. Catholic liturgy and culture.

\section{LA HISTORIA DE ALFONSA}

Alfonsa de la Torre, autora española perteneciente a la segunda generación española de posguerra, fue una poeta y estudiosa nacida en la localidad segoviana de Cuéllar en 1915. Hasta la fecha de su muerte, acaecida en 1993 desarrolló una obra poética no muy extensa y de desigual calidad que, no obstante, ha ido adquiriendo interés en los últimos años debido a ciertas características que la convierten en una voz original, muy potente en sus mejores momentos, y que desafía la inteligencia del lector para completar el sentido de sus textos.

Alfonsa de la Torre, hija de una familia muy acomodada, cuya rama materna, de estirpe nobiliaria, era descendiente de Pedro I el Cruel, recibió una educación formal muy superior a la media de las mujeres de su tiempo. Después de realizar en su localidad natal los estudios primarios, estudió el bachiller en Segovia. Allí hizo amistad con Dionisio Ridruejo y con Felipe Peñalosa. Con ellos participó en la organización de representaciones teatrales, un poco a imitación de "La Barraca" lorquiana.

Marchó después a Madrid, donde estudió Filosofía y Letras, siendo alumna de Pedro Salinas y Dámaso Alonso. Se ha conservado un cuadernillo con los apuntes de las clases recibidas de Salinas. Estos, prácticamente contemporáneos al momento en que Salinas elaboraba el concepto de 
generación del 98, se centran en el análisis de Campos de Castilla.

En la capital se relacionó con Carmen Conde, Josefina Romo y otras jóvenes intelectuales de la época, así como con escritores destacados de la primera promoción de posguerra. Se graduó como doctora en 1944 con una tesis sobre Carolina Coronado.

En varias entrevistas y aproximaciones biográficas se recogen datos muy interesantes acerca de la vida de Alfonsa (Cruset, 1979; González de la Torre, 2009; Imaz, 1961; Llorente et al., 2008; Quevedo, 1986), a la que me referiré seguidamente. Las precisiones más exactas acerca de su vida académica las hace Romano Colangeli (1964). Ciñéndonos a lo que actualmente se conoce acerca de la autora -ya que nos consta que se encuentra actualmente en preparación una biografía más completa cuya autora es $\mathrm{M}^{\mathrm{a}}$ del Carmen Gómez Sacristán-, podemos decir que, durante su etapa formativa, Alfonsa de la Torre recibió clases de lengua y cultura italiana, primero en el Instituto Italiano de Valladolid (curso 1938-1939) y después entre 1941 y 1943 en el Instituto de Cultura Italiana de Madrid. Obtuvo varias becas con las que amplió estudios de lenguas modernas: en 1944 siguió en Lisboa un curso de lengua y literatura portuguesas, y en 1945 amplió sus estudios de esta área en la universidad de Coimbra. Portugal sería, andando el tiempo, su país de adopción. Allí pasó largas temporadas y allí viajó en numerosas ocasiones con el objetivo principal de profundizar en el estudio de la pintora barroca conocida como Josefa de Óbidos, que ella identificó como Josefa de Ayala, nacida en Sevilla.

Entre 1941 y 1945 fue profesora en la Facultad de Filosofía y Letras de la Universidad de Madrid, como ayudante de Entrambasaguas. En este período, su actividad académica llegó a ser muy extensa: en un arco temporal que va desde 1941 hasta 1945 fue colaboradora en el Consejo Superior de Investigaciones Científicas, obtuvo una beca de la Real Academia de la Lengua para trabajar en el Centro de Estudios de Lope de Vega, impartió cursos de español para extranjeros en la Universidad Menéndez Pelayo y fue profesora en la escuela para bibliotecarios del Estado en Madrid.

Estos años que Alfonsa dedicó a la docencia fueron también los de sus primeras y más importantes publicaciones literarias, con la aparición de Égloga (1943a), Oda a la reina del Irán (1948) y Oratorio de San Bernardino (1950), que fueron rápidamente reconocidas por parte de la crítica española (Romo, 1943; Diego, 1951a y 1951b; Fernández Almagro 1943 y 1951, etc., la reseñaron) y de la internacional, campo en 
el que hay que destacar las aportaciones tempranas de la investigadora estadounidense Diana Ramírez de Arellano (1961) y de la italiana María Romano Colangeli (1964).

A pesar de que solo Égloga presenta rasgos de adhesión a la poesía formalista que cultivó un sector de su generación, es cierto que la autora tuvo relación con los dos núcleos fundamentales de la poesía oficial de la primera posguerra: el escurialense por su amistad con Dionisio Ridruejo -aunque no hay constancia acerca de cuál pudo ser la relación de Alfonsa con el grupo falangista durante los años de la posguerra-, y el garcilasista, por su asistencia ocasional a la tertulia del Café Gijón. De su relación con los integrantes de "Juventud creadora", el grupo de García Nieto, queda constancia en el $\mathrm{n}^{\mathrm{o}} 2$ de la revista Garcilaso, donde publicó una décima que, en tono desenfadado, describe algunos elementos del mundo natural: "De los surcos se levanta / de nuevo la espiga niña; / tanto soñó con ser piña / que no es ni trenza ni planta" (Torre, 1943b: s.p.).

Aunque las antologías generales han ignorado a Torre hasta una época reciente (Guillén, 2001; Reina, 2001), su poesía estuvo presente en la antología histórica de Carmen Conde, Poesía femenina española viviente (1954). Esta antología, a pesar de su descuido en aspectos importantes, como su falta de rigor en la bio-bibliografía de las autoras, y el caos teórico del prólogo, tiene el indudable valor de haber preservado para las generaciones futuras la noticia básica acerca de escritoras cuyo rastro probablemente se hubiera perdido. Aunque Alfonsa se manifestó crítica con la obra de su amiga, llegando a escribir que "después del prólogo-galimatías de la Antología de C.C. hemos quedado todas un poco "murientes"" que las antologías de poesía femenina que recogieron su obra, entre ellas la de Carmen Conde, han contribuido a preservar algunos poemas que, de no ser por ellas, se habrían perdido irremediablemente. Precisamente, en la antología de Carmen Conde se dan dos poemas, "Elegía a los niños del bosque de Bolonia" y "Evocación de Santa Inés", que tenían que haber formado parte de una "segunda edición renovada y completa de Oratorio de San Bernardino, que nunca llegó a publicarse.

Vale la pena mencionar también otra antología en la que aparece Alfonsa de la Torre. Aunque su aparición es tardía (1983), Versos con faldas, de Adelaida las Santas, incluye una selección de poemas pertenecientes a

2. Carta de Alfonsa de la Torre a Gerardo Diego, 25 febrero 56. Inédita. Archivo de Gerardo Diego. 
las autoras que participaron en unos recitales poéticos fundados en 1951 por Gloria Fuertes, María Dolores de Pablos y Adelaida las Santas. En respuesta a las numerosas tertulias literarias que ignoraban a las mujeres, ellas constituyeron esta alternativa exclusivamente femenina. La tertulia no sólo tuvo un carácter feminista, sino también descentralizador, facilitando que las autoras que, por no vivir en Madrid, tuvieran dificultades para asistir a ellas, se hicieran presentes enviando sus poemas por correo, siendo entonces leídos por actrices y locutoras voluntarias. La tertulia "Versos con faldas", como experiencia de difusión de la poesía femenina, no deja de ser interesante a pesar de que la continuidad de sus sesiones no se sostuvo más allá de dos meses (entre marzo y mayo de 1951), a partir de los cuales se producirían sólo esporádicas sesiones en fechas señaladas, como el día de la poesía. En la antología que décadas después se reuniría, figuran dos poemas de Alfonsa de la Torre.

Otras dos antologías especializadas en poesía de autoría femenina merecen también ser destacadas: la de Diana Ramírez de Arellano (1961) y la de Maria Romano Colangeli (1961). Se trata de dos trabajos importantes sobre la poesía femenina española contemporánea, que aportan inteligentes lecturas y datos precisos muy útiles para el investigador actual.

Ciertamente, todas las antologías que acabo de citar se publicaron con posterioridad a 1950, que es el año en que aparece Oratorio de San Bernardino y comienza la progresiva invisibilización de Alfonsa en el panorama académico y literario. No obstante, hasta ese momento, un prometedor futuro parecía abrirse ante ella en el terreno profesional.

Coincidiendo en el tiempo con la publicación de este poemario, se produjo el escándalo provocado por la concesión del premio Adonáis al libro Dama de soledad, de José García Nieto, aunque atribuido a una imaginaria Juana García Noreña. Ángeles Fernández de la Borbolla, que había iniciado poco antes su amistad con Alfonsa de la Torre, se vio involucrada en el escándalo al haber aceptado aparecer públicamente como autora del apócrifo poemario. Las circunstancias derivadas del engaño en el caso Dama de soledad llevaron a las dos mujeres a refugiarse en Cuéllar, en la casa de Alfonsa. Ángeles, que adoptó para siempre el nombre de "Juana", dependió económicamente de Alfonsa hasta la muerte de ésta. Alfonsa abandonó su carrera universitaria para interesarse por el patrimonio y los negocios familiares, de los que, en adelante, vivió. Dejó también de frecuentar con tanta asiduidad los ambientes literarios madrileños, pero no 
dejó nunca de estudiar ni de trabajar en su obra creativa: escribió poesía, narrativa y teatro, pero, desde entonces, sólo publicó dos libros de poemas -Epitalamio a Fabiola (1960) y Plazuela de las obediencias (1969)- y un relato breve, "Celdas para aparcar azucenas azules" (1974).

La personalidad de esta autora era la de una artista y una estudiosa, no la de una mujer de negocios. Ni ella ni ningún otro de sus familiares tuvieron capacidad para administrar los bienes recibidos, aunque la fortuna heredada bastó para vivir cómodamente muchos años, y con cierta austeridad durante los últimos tiempos. Alfonsa murió en abril de 1993 dejando como usufructuaria de sus bienes a Ángeles-Juana. Sus últimas voluntades no fueron respetadas por el único hermano de Alfonsa que le sobrevivió, lo que dio lugar a la venta y dispersión de su biblioteca y a un prolongado descuido de sus bienes, que provocó la pérdida de varios inéditos, por lo que es de temer la definitiva destrucción de gran parte de un legado intelectual que hubiera contribuido a iluminar también su obra poética.

Para aproximarse a ella, es preciso tener en cuenta que Alfonsa de la Torre fue una verdadera erudita, una persona apasionada por el saber que no dejó de estudiar nunca. Entre los temas de su interés se encontraban de forma destacada los relacionados con la magia, la alquimia, los fenómenos paranormales y la divulgación científica o seudocientífica, que ella abordaba, no obstante, con el mismo rigor metodológico con que se acercaba a la historia de la literatura o la historia del arte, sus otras pasiones.

\section{LA OBRA POÉTICA DE ALFONSA}

A instancias de su amigo José Cruset, Alfonsa se definió a sí misma como "una flecha lanzada hacia lo alto, en busca de una respuesta" (1979: 265). Su poesía parece, en gran medida, el instrumento de esa búsqueda personal. Completamente fuera de lo común, la poesía de Torre abre para el lector un gran número de interrogantes y revela una capacidad extraordinaria para la creación de un mundo poético totalmente personal.

$\mathrm{Su}$ profunda independencia artística e intelectual dificulta su filiación y ubicación literaria en un mundo cultural, el de la posguerra española, fuertemente ideologizado. En este sentido, Torre asimila diversos elementos de la poética oficial, aunque su discurso no solo no es afín al régimen, sino que lo contraviene en puntos importantes. Es cierto 
que, desde el punto de vista formal, el primer libro de la autora -Égloga-, contiene rasgos que se asimilan a la poética dominante de la primera posguerra, entre otras cosas, el formalismo métrico. El propio título de la obra es, por otra parte, un homenaje a Garcilaso, poeta que fue objeto de una clara instrumentalización en esos años. El apego a fórmulas métricas tradicionales, que domina con verdadera destreza, no sólo se refleja en la recuperación de los modelos renacentistas, sino también, y con especial finura, en las fórmulas métricas populares. Las tradiciones segovianas y su léxico dialectal comparecen también en esta obra, que destaca por una imaginería plástica y vigorosa.

Dos años más tarde, Alfonsa de la Torre daría a conocer su segundo poemario, Oda a la reina del Irán, inspirado por la imagen de Fawzia bint Fuad, la primera esposa de Mohammad Reza Pahlevi, último Shah de Irán, a través de cuya idealizada representación ofrece un modelo de feminidad sensual y despreocupada, en un entorno lujoso, contrapuesto al de la mujer real, imagen en cuya sombra se adivina la figura de la propia Alfonsa, y que viene simbólicamente definida por la austeridad y el desasosiego existencial.

Su tercer poemario, Oratorio de San Bernardino (1950) es, de toda su obra, el más maduro, acabado y complejo. La descripción de algunas claves interpretativas del mismo centrará el siguiente apartado de este artículo. La obra tiene un sentido espiritual y autoindagatorio, que explora su realidad íntima y expone de forma innovadora y transgresora la diversidad del colectivo femenino. La estructura de la obra se apoya en elementos ecfrásticos y simbólicos con los que hace gala de un marcado culturalismo.

Epitalamio a Fabiola (1960) es, en cambio, su libro más circunstancial escrito con ocasión de un acontecimiento social importante en la España como fue la boda del rey Balduino de Bélgica con la española Fabiola de Mora y Aragón. Alfonsa de la Torre, perteneciente a la nobleza de segunda fila como la propia Fabiola, quiso contribuir a la solemne ocasión del enlace con la edición de esta obra, que celebraba los esponsales y, particularmente, proclamaba y exaltaba la nueva condición de Fabiola como reina. Con el Epitalamio a Fabiola, Alfonsa de la Torre confirma su interés poético por las mujeres que ocupan el estatus social más alto (no olvidemos su Oda a la reina del Irán, ni tampoco su interés por la figura de la Virgen María en su advocación como Regina Coelis). A través de 
mujeres que simbolizan el ejercicio del poder, la autora incide de forma transgresora en la representación de la realidad femenina, lo que tiene una interpretación en la línea feminista, puesto que rompe con la imagen de la sumisión de la mujer, y otra en la línea de las creencias esotéricas de la autora, pudiendo ser estas figuras representaciones poéticas de la "mujer poderosa" del tarot, considerada como figura benéfica, aliada o mediadora ante fuerzas superiores.

Plazuela de las obediencias (1969), último poemario publicado por la autora, tiene un indudable interés temático, principalemente en puntos relacionados con la defensa de la mujer como generadora de conocimiento. La autora muestra su convicción de que la ciencia conducirá al ser humano a una versión mejorada de sí mismo, y al progreso continuado del conocimiento, ocupando la sabiduría femenina un lugar central en este proceso. Sin embargo, su carácter de autoantología, la anexión de poemas datados en períodos muy distantes, debilita el conjunto de un poemario que no puede estar a la altura del anterior.

Un balance global del conjunto descrito conduce a la conclusión de que, pese a la irregular calidad de su producción, la obra de Alfonsa de la Torre revela una personalidad rica y compleja, que arranca del formalismo clasicista para adentrarse en derroteros culturalistas y transgresores en la lírica de los primeros años de la posguerra. De forma más o menos encubierta, su poesía refleja una relación conflictiva con la ideología oficial de la época, especialmente en lo tocante al papel social de la mujer y en lo relativo a la vivencia de una espiritualidad elaborada desde creencias mágicas y sugestiones culturales, y no desde una religiosidad ortodoxa.

Respecto a lo primero, es necesario reparar en la galería de personajes femeninos que aparecen en su obra, que claramente reflejan modelos de feminidad alternativa (vid. Payeras, 2008), siendo necesario recalcar una vez más la importancia del discurso de esta autora, que problematiza la realidad de la mujer en el contexto político, social y cultural de la España de Franco.

No solo sus posiciones feministas colisionan con la ideología dominante de la posguerra. De forma más sutil, pero igualmente significativa, hay que señalar las características de la abundante temática religiosa de su obra, que solo en apariencia se acomoda al modelo de espiritualidad dominante en la época y que, por el contrario, se desarrolla a través de un doble discurso al servicio de inquietudes y especulaciones 
intelectuales propias.

En otro sentido, la obra deAlfonsa de la Torre, se anticipa notablemente al culturalismo característico de las poéticas novísimas y afines, acumulando en su obra referencias a las artes plásticas e incorporando un sinnúmero de referencias propias de la erudición académica, especialmente en temas vinculados a la literatura, la historia del arte, la simbología, etc. No sólo la extensa erudición acumulada en materias convencionales tiene reflejo en su obra, sino también aquella que la liga a saberes esotéricos, cultura popular, e incluso, a movimientos contraculturales. Su obra literaria es versátil en todas estas fuentes, y la suma de todas ellas es su característica más inconfundible.

Explorar los límites del conocimiento humano fue el acicate principal en la vida intelectual de Alfonsa, así como un tema esencial de su poesía que se desarrollaría siempre como vehículo de sus obsesiones y de su vasta cultura, convirtiéndose, a la vez, en soporte de una creatividad totalmente original que desvía la intención del texto hacia terrenos en los que busca, ante todo, la expresión de una subjetividad individual diferente, alternativa, definitivamente "otra" en el contexto artístico, social y moral de la época.

\section{ORATORIO DE SAN BERNARDINO}

Oratorio de San Bernardino (1950) es seguramente el libro más conocido de Alfonsa de la Torre, a lo que contribuye el hecho de que, además de haberse recuperado en los últimos años su Obra poética (2011), este poemario en concreto cuente con una edición actual en volumen exento (2016). Aunque, aparentemente, su discurso no despertó recelos de ningún tipo en la censura franquista, su sentido colisiona repetidamente con el discurso dominante, lo que demuestra que no fue bien entendido e interpretado. Por este motivo es conveniente ofrecer algunas claves de lectura que contribuyan a esclarecerlo.

\subsection{Simbología ecléctica}

Dentro de un contexto fuertemente simbólico y alegórico es necesario destacar el componente numérico que la propia autora subraya, indirectamente, en la introducción en prosa a esta obra cuya estructura tripartita se apoya en el simbolismo, de fuerte arraigo en la tradición 
bíblica, alquímica, cabalística, pitagórica, etc., del número tres y del número siete. No es superfluo, en el seno de un poemario inspirado en la cultura italiana, aludir, entre otras cosas, al uso de la simbología numérica en la Divina Comedia. La autora considera su libro como un solo poema, como una unidad dividida en tres "climas" o partes, cada una de las cuales incluiría siete poemas como fragmentos de un todo. En su descripción de la obra, la primera parte representaría un movimiento indagatorio en busca del conocimiento y la paz espiritual, la segunda supondría el beneficio catártico derivado de la armonía natural y espiritual, mientras que la tercera y última significaría para la autora el despertar, perplejo, a la realidad.

En términos generales la estructura obedece a una búsqueda espiritual que, aunque en la introducción se describe de forma distanciada, hablando del poeta en tercera persona, pronto involucra a la primera persona del singular en poemas muy significativos, como "Ante un prado" (" $i \mathrm{Oh}$, tú, que nada sabes, lecho de peregrino! / adéntrame en la calma de tu quieto oratorio!"), "Campanas sobre las colinas de la Umbría" ("No quiero que forméis telón de bronce, / cabeza de querubes mensajeros, / sino una escala de oro en los alcores / para trepar por la armonía al cielo"), hasta llegar a la autonominación en "Defensa de las virtudes" ("porque Dios les decía, / que el amor cambia el nombre, / que el amor gana el nombre / y mi nombre sonaba en sus labios a tarde, / sonaba a amaneceres, / a pimpollos de pino, / a julio entre los álamos, / a polen de mimosa. / Y Dios me repetía / que ese nombre era el mío, / que me llamaba Alondra, / pero yo bien sabía que me llamaba Alfonsa, y Dios bien lo sabía").

En cuanto al carácter alegórico de muchos poemas de Oratorio de San Bernardino, cabe recordar el carácter sincrético del simbolismo alfonsino. Sus fuentes provienen del simbolismo bíblico, cristiano, cabalístico, alquímico, etc., y su empleo literario procede de un caudal que hunde sus raíces en el inconsciente colectivo, a lo que Alfonsa hace referencia en papeles privados, manuscritos, que han sobrevivido de forma fragmentaria y se conservan inéditos, pero que dan testimonio de su intensa dedicación al estudio. Por otra parte, aunque no nos consta un especial interés de Alfonsa por las ciencias puras o por ciencias empíricas como la física y la química en las que es fundamental el empleo de símbolos -salvo el interés, al menos poético, por la alquimia-, hemos de tener en cuenta el valor de estos en temas como la psicología, la religión, las artes plásticas y otras disciplinas por las que sí nos consta que la autora se interesó activamente. 
Por otra parte, considerando su fascinación por las corrientes esotéricas, es preciso recordar que muchas sectas ocultistas se apoyan también en un rico patrimonio simbólico. De manera especial, su profundo interés por las artes plásticas, le llevó explorar la dimensión simbólica de las mismas, reflejándolo en su obra poética, tal como se pone de manifiesto en Oratorio de San Bernardino.

\subsection{El componente ecfrástico}

El poemario tiene un fuerte componente ecfrástico, como representación verbal del conjunto escultórico que forma la portada del Oratorio de los Santos Andrea y Bernardino en Peruggia. Obra del Duccio, esta portada es una verdadera joya del Renacimiento italiano.

El carácter mimético respecto a determinados elementos escultóricos del conjunto fue cuidadosamente destacado por la autora en la primera edición del libro, que no sólo reproducía en portada y en páginas interiores varias imágenes del Oratorio, sino que las acompañaba, a pie de página, con versos alusivos.

Alfonsa era una apasionada del arte, sobre todo de la pintura, pero también de otras artes más modernas, y lo demostró en las ilustraciones de su obra. Las estampas del poemario proceden de fotografías originales de la casa florentina Alinari, la empresa familiar de fotografía más antigua del mundo, entre cuyos trabajos se cuenta una obra sobre los Paisajes italianos en la Divina Comedia. Sobre estas fotografías, las fototipias que aparecen en el libro son de la casa Hauser y Menet, una antigua empresa de fotógrafos editores de Madrid que colaboraban semanalmente en la revista Blanco y Negro.

En la imaginación de Alfonsa, las figuras del Duccio cobran vida. Es el caso de "Defensa de las virtudes": "porque Dios lo quería / despertaba virtudes esculpidas en mármol. / Virtudes que tenían talla de primavera / y en los labios cerrados la bondad de las rosas". En "Irrumpieron los ángeles", también, se produce un interesante juego descriptivo y conceptual: primero, la autora describe los bajorrelieves como materialización de los espíritus angélicos -"Chocaron contra el mármol teñido de crepúsculo, / chocaron contra el cielo sus voces y tiorbas / y eran los instrumentos en sus brazos amantes / dóciles bestezuelas gimiendo de ternura"-, mientras que, a continuación, después de que lo espiritual se materialice en la piedra, 
la materia se espiritualiza y abandona sus límites naturales -“Todos los elementos dejaron la materia, / cesaron en sus cargos al sentir el concierto; / ni nubes, ni metales, ni gemas ni amapolas: / irrumpieron los ángeles"--

Ahora bien, el poema donde más se recrea la autora en la descripción de uno de esos bajorrelieves es "San Bernardino":

Pájaro aprisionado en una almendra, polen de flor entre rumor de estambres, llama votiva que en el mármol arde, hoja caída en plácida pradera. Ojo de Polifemo que se encueva ávido de ternuras recentales, sacra custodia alzándose en la tarde, pomo de aroma fecundando piedra. Lirio en fanal que el tiempo no conmueve, viscera conservada en relicario, bálsamo de hermandad, matriz, estola. Ara, patena, cirio y hoja verde, corzo en redil y antílope de álamo, ramo de menta abriéndose en la Gloria.

Es visible en el texto la acumulación de imágenes sobre un mismo elemento, recurso que, en este caso, tiene una función descriptiva. La acumulación de imágenes es muy recurrente en la poética de Torre. La autora despliega un vasto número de analogías que representan de manera muy plástica la imagen escultórica: "pájaro en una almendra", "polen entre estambres", "llama que arde en mármol", "ojo de Polifemo", "custodia alzada", "pomo que fecunda piedra", "relicario", "corzo en redil", "ramo de menta".

En este caso, las imágenes se mueven en torno a varios grupos semánticos. Uno de ellos es el de la naturaleza: "pájaro", "almendra", "flor", "estambres", "hoja", "pradera", "recentales", "lirio", "corzo", "antílope", "álamo", "ramo de menta". Otro es el de la liturgia: "llama votiva", "custodia", "relicario", "ara", "patena", "cirio". Menos numeroso es el que vincula sensualidad y catarsis: "pomo de aroma fecundando piedra", "bálsamo de hermandad" y ya, excepcionalmente, la referencia mitológica y literaria al ojo de Polifemo. 
La iconografía del oratorio de Peruggia tiene un indudable protagonismo en el poemario, abasteciendo de imágenes la fértil creatividad de la autora que ordena, a través de ellas, un mundo de referencias sensoriales, pero también conceptuales en la construcción de su personal aprehensión de la realidad.

\subsection{El homenaje a la cultura italiana}

Después de considerar la representación que hace la autora de esta obra de arte, es necesario hacer referencia a un aspecto muy sobresaliente del poemario como es el continuo homenaje que hace a la cultura italiana. En primer lugar, como acabamos de ver, Italia está presente en sus obras de arte así como en la selección de ilustraciones, obra de fotógrafos italianos. El paisaje italiano -sobre todo el paisaje natural-, está muy presente tanto en el imaginario de la obra como en el plano descriptivo. Un ejemplo notable sería el poema "Letanía primaveral a María en la Riviera dei fiori", al que más adelante me referiré. Por supuesto, la cultura italiana se visibiliza también en sus referentes literarios. En este caso, hay homenajes bastante explícitos a Dante y a Francisco de Asís. La tradición espiritual italiana, en parte representada por los mismos escritores, está también señalada en poemas que la autora dedica a San Bernardino de Siena, a Santa Catalina de Siena (patrona de Italia), a Santa Cecilia, a San Francisco (que no solo es poeta sino patrón, a su vez, de Italia), etc. En referencia a este último, si antes me he referido a la estructura del poemario como un implícito homenaje a Dante, no puedo dejar de mencionar el franciscano amor de Alfonsa por la naturaleza. Deleitarse en la belleza natural es un rasgo de la personalidad de la escritora, no sólo un tema recurrente en su obra. Basta leer algunas de sus cartas personales para comprender hasta qué punto vivía atenta a la transformación cíclica y a la belleza del mundo natural. En la fraternidad franciscana hacia las criaturas encuentra la escritora su propio reflejo. En este sentido, la letanía poética que antes he mencionado, tiene una interpretación -no la única, desde luego-, como homenaje al "poverello" de Asís.

\subsection{La liturgia católica}

El poema anterior nos permite introducir otro de los elementos 
recurrentes del poemario, que es el referido a la reescritura de textos y fórmulas propias de la liturgia católica. Baste para ello señalar algunos títulos, además de la "letanía" que acabamos de ver: "Himnodia a las espigas", "Antífona de Santa Cecilia", "Cantata mística" y "Sermón de San Francisco a las flores". Formalmente, cada uno de estos poemas se acerca de algún modo a las fórmulas referidas, no de forma mimética, sino reinterpretándolas. "Antífona", "Himnodia" y "Cantata" designan fórmulas litúrgicas frecuentemente cantadas, lo que está en consonancia con la musicalidad métrica de muchos de los poemas, y con el carácter sacro, de ascensión mística, que la música tiene en Oratorio, como, por ejemplo, en "Irrumpieron los ángeles" o en "Campanas sobre las colinas de la Umbría". La antífona está dedicada a Santa Cecilia, patrona de la música. La "himnodia", como canto celebratorio, se presenta temáticamente como una invitación a alabar a Dios. La "Cantata mística" está dedicada a Santa Catalina de Siena, que tiene consideración de doctora de la Iglesia, en uno de los numerosos guiños de Alfonsa de la Torre a la inteligencia femenina. Esta santa fue una monja emprendedora y activa en la vida pública de una Italia muy lejana a su unificación. Se la venera también como una mística destacada, de ahí el título del poema. El sermón de San Francisco, por su parte, responde totalmente al modelo textual del género, en su carácter de amonestación, enseñanza moral, etc.

Estos elementos de la liturgia se avienen con el carácter religioso del conjunto arquitectónico y escultórico que inspira el poemario, con las figuras del santoral que recrea, con las referencias a Dios, a los ángeles, a la Madonna, etc. Los poemas hagiográficos desarrollan episodios concretos relacionados con la leyenda o la historia que se atribuye a cada uno de ellos.

Todo ello crea un conjunto de evidentes connotaciones espirituales, por lo que la superficie de los textos puede ser vista, y así se interpretó en su momento, como una obra de temática religiosa, como tantas que hubo en aquellos años, sin despertar el recelo de segundas intenciones.

Los aspectos simbólicos, ecfrásticos e italianizantes del poemario forman parte de la complejidad estructural de la obra, pero no ofrecen, en su superficie, elementos conflictivos o de confrontación con la ideología dominante de la época. La hermenéutica de esta obra exige, no obstante, considerar la funcionalidad de la superposición de planos textuales en ella, que contribuyen a generar dobles sentidos en el discurso. 


\subsection{La superposición de planos textuales}

De igual manera que superpone imágenes sobre un mismo concepto (como antes he querido reflejar al detenerme en el poema dedicado a la imagen de San Bernardino) o sobre un mismo referente (como el lector puede comprobar en otros muchos poemas de Oratorio de San Bernardino, como "Amazonas veladas" o "El juicio de Lilith"), es también habitual que la autora superponga distintos niveles en un texto. Un ejemplo, en este caso, sería "Ante un prado":

He aquí un prado.

Ante mi un prado.

Un placentero y recogido y sedentario prado.

Mis ojos están cansados de ver prados.

prados usados con pesadez de romerías,

con colas de ermitas viejas marchitándose en sus cirios;

prados de la Asunción y de San Juan,

lumínicos prados de Pascua.

Mis ojos han visto prados

$y$ de tanto extasiarse en ellos

no saben lo que es un prado.

Este es el comienzo del poema, mucho más extenso, como suelen serlo la mayor parte de los que integran esta obra. En él, a partir de la imagen inicial del prado, el poema avanza abriendo progresivamente nuevos niveles representativos.

En primer lugar se percibe el plano referencial. El Oratorio de San Bernardino, una pequeña iglesia de Peruggia, se encuentra situado en el conjunto monumental de "San Francesco al prato". El motivo de inspiración para la autora se encuentra, pues, ubicado en un prado.

Avanzando en el texto, la realidad inmediata se abre al plano evocativo. El prado en el que se encuentra el sujeto poético, interpretado como punto de peregrinaje, despierta en la conciencia la evocación de viejas romerías: "Mis ojos están cansados de ver prados, / prados usados con pesadez de romerías / con colas de ermitas viejas marchitándose en sus cirios; / prados de la Asunción y de San Juan, / lumínicos prados de Pascua". Desde ese punto pasa el poema al plano indagativo. Ante la realidad 
inmediata, la autora quiere comprender la esencia del objeto, y lo define desde distintos ángulos. Desde un ángulo simbólico se pregunta si el prado es la esperanza de la tierra, desde un ángulo metafórico se pregunta si es el vello varonil de la tierra, desde un ángulo retrospectivo imagina que pudieron, alguna vez, surcarlo ocas egipcias... Pasando seguidamente a un plano contemplativo, habla de ese mismo prado donde ahora se encuentra, reconstruyendo su pasado, cuando fue descubierto por frailes visionarios, para quienes se obraría el milagro de la eclosión sublime de la naturaleza: "chorrearían trinos, / destilarían luces, / centelleos de mármol, / orgías de sonidos...". En un último nivel, la misma peregrina se dispone a apropiarse del prodigio, de modo que, por último, en un arrebato místico, ansiosa de fusión espiritual y de conocimiento, imagina esa ansiada plenitud -reinterpretando la mística tradicional- como un abrazo de amante: "Mi beso será un beso cargado y penetrante, / con potencias de siglos, / con deseo de muerte, / un beso de suicida o de amante sin freno; / de ahogado ya sin fuerzas / será mi firme abrazo / y de enfermo sin prisa mi caliente cobijo. / ¡Oh tú que nada sabes de saberlo ya todo!, / acógeme en tu seno...”.

Sobre esta base de planos superpuestos $-\mathrm{y}$, a veces, contrapuestosse fundamenta también mi propuesta de interpretación de todo el poemario. En primer lugar, creo que la espiritualidad de Alfonsa, muy sincera y poderosa, debe ser separada de cualquier creencia convencional y ortodoxa. Formalmente, llevó la vida de una católica practicante. Durante sus estancias en Cuéllar se relacionaba mucho con la comunidad de frailes del Santuario de Nuestra Señora del Henar, con cuyo prior, el padre Balbino Velasco, tuve también yo ocasión de conversar en 2011. Él la veía como una fiel devota, y me comentó que la escritora, anualmente, becaba a sus expensas a un seminarista. Pero también creía que su feligresa era una persona singular, algo imprevisible en sus actuaciones. $\mathrm{Y}$ aunque, indudablemente, se mostraba, en las formas, respetuosa con la Iglesia Católica, no es menos cierto que su espiritualidad era una elaboración sincrética personal. Las fuentes biográficas ya mencionadas, así como la consulta de algunos papeles personales de la autora revelan que, a pesar de las apariencias, Alfonsa sostenía creencias como la de la reencarnación, rechazadas por la Iglesia Católica, realizaba prácticas adivinatorias, mágicas y supersticiosas también condenadas por esta, le interesaban enormemente las ciencias herméticas o esotéricas y asociaba a la magia el origen de las religiones. Todos estos aspectos hacen de Alfonsa 
de la Torre una creyente poco ortodoxa y pondrían por sí solos en tela de juicio la religiosidad convencional de un poemario como Oratorio de San Bernardino si el propio texto no lo refrendase también con mecanismos propios.

Es necesario precisar, por otra parte, que los planos superpuestos y entrecruzados en la poesía de esta autora incluyen -para la autora en un mismo nivel-, las cuestiones científicas y paracientíficas. En este sentido, conciliaba el interés por los saberes ocultos con el análisis científico de los fenómenos. Un ejemplo claro lo suministra su interés por la interpretación de los sueños. En este sentido, su interés se afirmaba en las teorías psicoanalíticas, especialmente tamizadas por Jung, gran estudioso de la alquimia, pero la autora no sólo les daba un valor para interpretar la conducta o las emociones del sujeto, sino que también las consideraba como vías hacia la clarividencia. Ella misma creía poder predecir el futuro a través de la interpretación de los sueños. Otro ejemplo de asociación de aspectos racionales e irracionales en el pensamiento de la autora tiene que ver con su erudición respecto a fenómenos paranormales, que ella intentaba explicarse a través de lectura de obras de divulgación científica o pseudocientífica. Le interesaba también la literatura que tratara de fenómenos insólitos, sin atender a su jerarquía en cuanto a la calidad literaria: Jorge Luis Borges, Lovecraft, Arthur C. Clarke, etc.

Se aproximaba a lo desconocido con un espíritu abierto y creía que la ciencia avanzaría hasta explicar racionalmente fenómenos que en la actualidad se niegan desde supuestos racionalistas, y lo que hoy se representa como absurdo, podrá ser una verdad universalmente reconocida, como lo son hoy la esfericidad de la tierra o el funcionamiento del sistema solar. En ese entendimiento, se sentía fuertemente atraída por las cuestiones paranormales. Entendía la magia y la brujería como eslabones del progreso, por lo que las hechiceras, magas, brujas, etc., aparecen en sus obras sin estigmas. No debemos olvidar que las llamadas "brujas" en las comunidades tradicionales eran mujeres con un gran conocimiento del medio natural, que aplicaban remedios a través de plantas y productos naturales cuyas propiedades terapéuticas son hoy reconocidas por la comunidad científica. Desde otra perspectiva, la alquimia, otra de las disciplinas que le interesaron, tiene, junto a una dimensión esotérica, la de ser el precedente más directo de la química contemporánea.

Aunque estas cuestiones no tienen en Oratorio de San Bernardino la 
presencia que adquirirán, posteriormente, en Plazuela de las obediencias, es forzoso tenerlas en cuenta si se considera que el poemario se asienta en numerosos elementos de la liturgia, la tradición y la espiritualidad de la religión católica, ya que, en el pensamiento de Alfonsa, es muy tenue la línea que separa la religión oficial de la magia. Como antes he señalado, la autora se muestra consciente de que las religiones tienen su origen en la magia. En unas anotaciones inéditas de su puño y letra apunta la siguiente observación que atribuye a Rasmussen: "La idea religiosa tiene al menos en parte, un origen común con la magia, pero difiere en los medios". Conociendo sus aficiones esotéricas, no podemos tampoco dejar de señalar el paralelismo de figuras entre el santoral católico y la santería o la importancia de las figuras angélicas (tan relevantes en Oratorio de San Bernardino) tanto en la tradición judeocristiana como en la teosófica o en la esotérica.

\subsection{Ironía y parodia aplicada a elementos religiosos}

Lo que hasta aquí queda apuntado desestabiliza, como mínimo la idea de la religiosidad convencional de Alfonsa de la Torre. Falta ahora apuntar rasgos que sugieren un empleo irónico o paródico de algunos elementos religiosos. Este rasgo es, casi siempre, muy sutil, ya que la censura religiosa era muy fuerte todavía en la España de 1950. En una ocasión, por ejemplo, el renuevo de la naturaleza insinúa la idea de la reencarnación, pero manteniéndola en un plano imaginario: "Las hojas, los capullos, las alas ya marchitas, / los ojos que ya dieron su cosecha de amores, / las carnes que aromaron las sedas y los linos / volvían en reflejo de esquiva primavera. / Volvían las gaviotas, las doncellas más puras / florecidas en calas y en lirios no soñados / se alzaban los guerreros como verdes laureles...".

Tanto el santoral católico como los sermonarios clásicos fortalecen un modelo de feminidad asexuado y, en general, se orientan al control de la conducta de la mujer. En este sentido, "Sermón de San Francisco a las flores" reproduce un catálogo de recomendaciones morales que instan a la mujer a ser modesta en su arreglo personal, austera, etc. Se dirige a las flores ofreciéndoles consejos similares a los consabidos para las mujeres, insertando su discurso en la larga la tradición que las asimila a las flores. Algunas poetas de la generación de Torre, de manera señalada Ángela 
Figuera, alzaron su voz contra esa analogía. ¿Cabe pensar, entonces, que nuestra autora reproduce acríticamente un discurso patriarcal que aconseja a la mujer suprimir "cuchicheos prolongados", evitar el "vaivén de cinturas en el aire", limitar el aseo a "solo lo preciso", ser hacendosas y evitar "el ocio que es muerte"? Desde luego que no. Alfonsa fue, en España, una de las primeras mujeres modernas. Formó parte del círculo amistoso de Carmen Conde en su juventud, de esa Carmen Conde que levantaría la voz en su libro Mujer sin Edén, de 1947 -tres años anterior a la publicación de Oratorio de San Bernardino - contra la marginación histórica del colectivo femenino y que lo haría, justamente, subvirtiendo el discurso patriarcal de la Iglesia. Con todos estos datos en la mano, el discurso de Alfonsa en el "Sermón de San Francisco a las flores" sólo es coherente si se interpreta en un sentido irónico.

También cuando reproduce en su poemario los modelos femeninos del santoral romano se percibe un sutil ejercicio de reescritura que no afecta a la leyenda hagiográfica-demostrando un buen conocimiento de las respectivas historias de las santas-, pero sí a su interpretación. El martirio de Santa Cecilia, una de las santas que aparecen en el libro, está asociado a la defensa acérrima de su virginidad, igual que el de Santa Inés, que no llegó a incluirse en la primera edición del poemario pero que estaba previsto para la segunda y que se publicó en la antología de Carmen Conde (1954: 341-344). La autora mantiene en ambos casos un tratamiento ambiguo del tema. Por una parte, refleja la historia tradicional de esas mujeres sin alterarla. Por otra, introduce sutiles reticencias al modelo que encarnan, rebatiendo principios asentados en la tradición moral recibida. En este sentido, el tema de la virginidad, que aparece tradicionalmente vinculado al ideal extremo de castidad femenina avalado por la moral católica, no se reconoce en la poesía de Alfonsa como un valor absoluto, sino más bien como algo estéril y sin valor: "algo redondo y terso, / algo circularmente cerrado / que atrae con su brillo inmóvil / de agua no usada, / de agua que no sirve más / que para encerrarse y morir / superando círculos".

Por otra parte, la "Antífona a Santa Cecilia" alude a los muchos tormentos que la mujer hubo de sufrir, según la tradición hagiográfica, antes de su muerte. El poema mantiene un tono solemne que se quiebra repentinamente casi al final, cuando inventa una especie de onomatopeya basada en la tipografía e introduce un juego de palabras, un doble sentido polisémico, incongruente con el tono general del poema: “¿Quién pone 
frescos gladiolos / a los pies de tu escultura? // Aún sigue mi ángel custodio / las huellas de mi figura. // [...] // Con los dedos de la mano//lanzo yo mi dulce trino: / Uno y Trino / Trino y Uno // Uno y Triiino".

La súbita ruptura tonal destruye la solemnidad inicial del discurso y lo desestabiliza, introduciendo un punto de suave humorismo e ironía.

De forma similar, la autora reescribe la liturgia cristiana, siendo el ejemplo más claro de esa praxis su "Letanía primaveral a María en la Riviera dei Fiori".

El poema, desarrollado íntegramente en latín que por aquel entonces era la única lengua litúrgica, enumera más de un centenar de especies botánicas -árboles, arbustos, flores y hongos- referidas a variedades ornamentales, medicinales, comestibles, etc., denominándolas por su nombre científico. Entre ellas, tal vez involuntariamente, aunque yo creo que más bien humorísticamente, se filtran varias denominaciones incongruentes con el contexto por corresponder a nombres de animales. El poema culmina con una versión alterada del "Agnus Dei”: "Agnus Dei, qui tollis carduus mundi, / parce rosis Domine / Agnus Dei, qui tollis carduus mundi, / exaudi nos Domine. / Agnus dei, qui tollis carduus mundi,/ miserere floris". En conjunto, el poema tiene un sentido más bien pagano, relacionado desde el mismo título con una conocida ruta turística italiana -la Riviera dei Fiori-, y su desenfado no evita un toque de humor final que a algunos podría parecer irrespetuoso. El tono, nuevamente, desestabiliza el discurso convencional, desestructura la solemnidad litúrgica y acaba por ser un canto vitalista a la energía que brota de la naturaleza, así como una exaltación a la belleza y al placer sensorial que las flores derraman sobre la tierra y que las hace preferibles a los molestos o penitenciales cardos.

Aceptando, a partir de los modelos anteriores, el carácter lúdico con que la autora utiliza el lenguaje religioso, puede entenderse el sentido paródico del desmesurado elogio del martirio, representado en la siega del trigo, que aparece en "Himnodia a las espigas".

Los ejemplos mencionados permiten establecer el empleo libre y poco convencional que hace la autora de los modelos litúrgicos. Justo es decir que, no obstante, que en algunos instantes poéticos, la representación de la naturaleza como imagen de espiritualidad gozosa resulta mucho más sincera y conmovedora: "No hay flores que seque el viento / ni que agosten los sentidos. / La paz y el amor unidos / viven en entendimiento. / Si seguro es el contento / más segura es la armonía. / Abejas de alegoría / enjam- 
bres de luz gloriosos / vuelan sin paso, gozosos, / libando en Dios alegría".

\subsection{La imagen de la mujer}

Este tema, uno de los más relevantes en relación a la poesía de la autora y desarrollado ya en un artículo sobre las figuras femeninas en la poesía de Alfonsa de la Torre (Payeras, 2008), exige ser tenido en cuenta en la lectura global de Oratorio de San Bernardino.

En relación a este tema es necesario concluir que Alfonsa de la Torre defiende en su poesía la idea de que las mujeres son eslabones olvidados en la cadena que conduce al progreso del conocimiento, y promueve su reconocimiento como intelectuales. Complementariamente, rompe con los esquemas que muestran una imagen sublimadora y quintaesenciada de la mujer, ofreciendo otros ejemplos de feminidad, no como modelos, sino como muestras de la diversidad que el mundo femenino encierra. En Oratorio de San Bernardino, curiosamente, se ofrecen modelos de conducta femenina opuesta y extrema: santas y mártires o perversas hijas de Lilith, que es uno de los personajes que aparecen.

Puesto que ya me he referido a las santas, recordaré la existencia paralela de pecadoras y mujeres de perdición, las que representarían, en la estructura tripartita de la obra, a las criaturas diabólicas, insertas en la tercera parte del poemario. Siete poemas representarían los siete círculos infernales de Alfonsa, a diferencia de los nueve de Dante, concediendo el protagonismo a las mujeres, a las que corresponderían cinco de los siete círculos, y en los que se haría referencia a Lilith, a las "amazonas veladas", a las "infanticidas", a la "muchacha que caminaba a través del viento" e incluso la propia "Madonna". Es difícil asimilar la idea de que Lilith y la madre de Dios ocupen el mismo espacio, conciliándola con la idea del infierno como lugar donde los pecadores purgan eternamente sus pecados, según la tradición religiosa, por lo que se impone afinar las ideas en busca de una lectura comprensiva del conjunto.

Por una parte, si se toman las referencias de mujeres como Lilith, las infanticidas o las veladas amazonas que representan la idea del eros lésbico, se ven reunidas imágenes femeninas contrarias a la moral católica $\mathrm{y}$, por lo tanto, contrapuestas a los modelos que anteriormente se vieron, vinculados al santoral romano. En este sentido, Alfonsa adoptaría la clásica confrontación de modelos extremos que la tradición eclesiástica, desde 
San Ireneo, ha resumido en el anagrama AVE/EVA, es decir, la mujer angelical y la pecadora irredenta. Entre todas ellas, es Lilith la que encarna el mal en estado puro. El larguísimo poema que Alfonsa le dedica refleja la escena del Calvario, en que Cristo muere para redimir a la humanidad, reproduciendo todos los hechos sobrenaturales que los evangelios de Mateo y Marcos describen, sólo que el poema -no por cierto los textos bíblicosseñala a Lilith como la culpable máxima.

Lo que el poema reproduce, en este caso, es la misoginia eclesiástica, que responsabiliza a las mujeres de los males de la humanidad, estableciendo un doble rasero para las culpas masculinas y femeninas. Una vez más, comparece el doble sentido, el componente irónico, bajo la engañosa superficie, como característica de la autora. Lilith, responsable individual de sus propias culpas, cargaría también con las de todo el colectivo humano. En este sentido, y no por ser una criatura maléfica, arrastraría ella su propio infierno. Correlativamente, las "infanticidas" que buscan recuperar a sus hijos ("Buscan a sus hijos por el perfume de sus noches / buscan a sus hijos por la epidermis de las flores, / buscan a sus hijos por el plumón de los nidos"), las "amazonas veladas" que "traicionaron al amor" disimulando su verdadera condición y hasta la Madonna, cuyo hijo ha tenido que morir para redimir a la humanidad, y llora heladas lágrimas viven, cada una en sus circunstancias, su personal infierno. Mujer sin Edén (1947), de Carmen Conde, libro que abre en la posguerra un discurso rebelde de la mujer contra su secular marginación, también representa a Eva y a María igualmente como víctimas de la sociedad patriarcal. La conclusión de ambas, a mi modo de ver, es que la excelencia moral no es ningún salvoconducto que libre a las mujeres de una similar experiencia trágica.

\section{UNA VIDA A CONTRA CORRIENTE}

Aceptando la pluralidad de sentidos que encierra el poemario estudiado, cuyas claves se han ido desvelando, es necesario concluir tratando de encontrar en la diversidad de elementos tratados un elemento unitario, que arranca de la idea de la mujer que peregrina en busca de la paz interior, que busca, subjetivamente, armonizar su identidad personal, sus particulares opciones morales, con un pensamiento espiritual en el que pueda integrarse. En este sentido, el poemario tiene un plano autoindagatorio y autoafirmativo en el que hay poemas muy reveladores. Tomemos, 
por ejemplo "Encuentro con el amor". Nada hay en este poema del Dios terrible que juzga a Lilith, sino el rostro apacible del ilimitado amor de Cristo: "verdadero como la luz, / insondable de ternura como los ojos de las gacelas, / sin ecos, como el amor de Cristo, / y sin recompensa, como la Redención". Pero, junto con la idea de una espiritualidad cálida e integradora, el poema recoge también la idea de un amor esquivo, que no se corresponde con una vivencia del amor realizado, o, en otra lectura, que no se corresponde con los patrones heteronormativos: "Creían que eras todo eso, amor: / calideces de nido, / entornamiento de alas, / perderse al atardecer por veredas risueñas // [...] // Amor, amor. ¡Cómo mentían! / Te soñaron con prodigalidad de millonarios, / con lujo y metáforas de poetas supremos. / Amor, amor.jCómo mentían!". Queda implícita en el texto la cuestión de la orientación sexual del sujeto poético.

Por supuesto, en este plano hay un poema ineludible, que es "Amazonas veladas", mujeres que disimulan su verdadera condición, pero que evitan a toda costa los "montes nupciales". La imagen andrógina de las amazonas mitológicas, evoca en el poema el concepto de sexualidad lésbica, asociándose al carácter binario, disémico, de numerosas imágenes utilizadas en el poema. Temas como la homosexualidad, la bisexualidad y la androginia aparecen en algunas notas manuscritas de Alfonsa. En uno de sus papeles, bajo una línea que encadena los nombres de Hipócrates, FreudArturo Castiglione (sic.) y Santayana, escribe lo siguiente: "Creencia en un ser bisexual, anhelo de una bisexualidad mágica, mística y sobrenatural, que tiene su origen probable en la bisexualidad fisiológica y psicológica de la raza humana". El interés de Alfonsa por el tema del andrógino, que aquí se explicita, tiene especial relevancia en el poema "Letanía y ronda de las sórores mysticas ante el horno alquímico", de Plazuela de las obediencias (1969), referido a las sorores místicas, las mujeres alquimistas, siendo uno de los mitos de la alquimia la búsqueda de la unidad perdida simbolizada en un principio hermafrodita, lo que refleja una pauta de ideas confluyentes en el pensamiento de la autora.

En este contexto, no es extraño que Alfonsa represente su alter ego en la "Canción de la muchacha que caminaba a través del viento", criatura que también vive su infierno particular arrostrando las dificultades cotidianas de quien actúa sistemáticamente a contra corriente. Es este, entre todos los poemas del libro, el que se presenta con un carácter más íntimo y personal, pero se ha de considerar en el contexto general del poemario, 
cuyo carácter autoindagatorio tiene en "Defensa de las virtudes" uno de sus pilares centrales. La peregrina se presenta ante Dios, un Dios al que nada se le oculta, que la acepta bondadoso y que permite a las virtudes de piedra cobrar vida en su defensa: "y cambiaban mi nombre, / el que Dios conocía, / el que Dios me curaba a fuerza de quererme / hasta lograr salvarlo; [...] // porque Dios les decía / que el amor cambia el nombre, / que el amor gana el nombre [...] / Y Dios me repetía / que ese nombre era el mío, / que me llamaba Alondra, / pero yo bien sabía que me llamaba Alfonsa, / y Dios bien lo sabía"

La autonominación, en este poema, es el indicativo de la búsqueda subjetiva que el poemario refleja, pero hay otro aspecto interesante, que tiene que ver con otra cuestión que la autora anota en sus estudios acerca de la magia. Atribuyéndole a G. Zillborg (sic.) la afirmación, anota: “cambiar de aspecto o de nombre es un concepto mágico también. Cambiarse el nombre equivale a un cambio real y efectivo de la personalidad"3. El fragmento parece representar una invitación de Dios a trascender, sublimar y transformar su naturaleza, que se resuelve en la aceptación de ambos, creador y criatura, de su auténtica personalidad.

La poesía de Alfonsa de la Torre, una de las más logradas y originales de su tiempo, se presenta en la actualidad como un desafío para el lector. Las distintas capas de sentido que se superponen en los poemas, su arquitectura simbólica, su elaborado imaginario, la muestran como una autora rica en matices, de orientación culturalista y, también, como una mujer adelantada a su tiempo. Oratorio de San Bernardino es un libro que contiene una invitación a la búsqueda del conocimiento y a la espiritualidad, al mismo tiempo que, tanto en la construcción de las figuras femeninas como en el distanciamiento irónico de algunos textos, resalta el conflicto de la autora en relación al poder patriarcal y a la religiosidad concebida desde una mentalidad punitiva.

Quizá el largo poema efectúa un camino inverso: desde el convencimiento de la aceptación de Dios, la peregrina cuestiona una tradición que margina a la mujer y que no integra modelos que rompen el orden social pautado. El temor que le han infundido al implacable juicio de un dios vengador es para ella un temor infundado, aunque se vea obligada a encriptar el mensaje de una verdad personal que la sociedad y la moral convencional

3. Nota manuscrita inédita. 
reprimen. Tal vez de esta convicción proceda el reproche moral del poemario hacia los "turistas" de la vida, que pasan por ella sin ver su verdadero entorno y sin implicarse en él.

\section{REFERENCIAS BIBLIOGRÁFICAS}

CONDE, Carmen (1947). Mujer sin Edén. Madrid: La autora. (1954). Poesía femenina española viviente. Madrid: Arquero [Reed. Poesía femenina española: 1939-1950. Barcelona: Bruguera, 1967.] CRUSET, José (1970). "Alfonsa de la Torre: en sus iluminadas soledades sin tiempo". En Valores de mi tiempo. Notas de Literatura Española, 259-265. Barcelona: Taber.

DIEGO, Gerardo (1951a). "Alfonsa de la Torre". El Adelantado de Segovia, 28 de abril.

(1951b). "Alfonsa de la Torre". A.B.C. (Madrid), 26 de abril, 3.

FERNÁNDEZ ALMAGRO, Melchor (1943). "Égloga, por Alfonsa de la Torre". A.B.C. (Madrid), 23 de mayo, 22.

(1951). "Ecos de la vida literaria: Oración por la paz”. La Vanguardia Española (Barcelona), 1 de marzo, 12.

GONZÁLEZ DE LA TORRE, Jesús (2009). Vida de Alfonsa de la Torre. Madrid: Eila Editores.

GUILLÉN ACOSTA, Carmelo (2001). Poesía Española 1935-2000. Barcelona: NyC.

IMAZ, M. J. (1961). “Alfonsa de la Torre (Biografía breve)". Revista de la Institución Teresiana (Madrid), enero, 3.

LAS SANTAS, Adelaida (1983). Versos con faldas. Madrid: Gráficas DoMo.

LLORENTE MÍNGUEZ, Juan Carlos et al. (2008). El palacio de Pedro el Cruel. Segovia: Cámara de Comercio.

PAYERAS GRAU, María (2008). "Figuras femeninas en la obra de Alfonsa de la Torre". Signa 17, 249-272 (también en http://www. cervantesvirtual.com/obra/figuras-femeninas-en-la-obra-de alfonsa-de-la-torre-0/ [01/03/2017]).

QUEVEDO, Juan Pablo (1986). "Alfonsa de la Torre, poetisa de Castilla". El Adelantado de Segovia, 29 de agosto, 12-13. 
RAMÍREZ DE ARELLANO, Diana (1961). Poesía contemporánea en lengua española. Madrid: Murillo.

REINA, Manuel Francisco (2001). Mujeres de carne y verso. Antología poética femenina en lengua española del siglo XX. Madrid: La Esfera de los Libros.

ROMANO COLANGELI, Maria (1964). Vocci feminili della lirica spagnola del "900". Bologna: Patrón.

ROMO ARREGUI, Josefina (1943). "Prólogo”. En Égloga, A. de la Torre, 9-23. Madrid: Hispánica.

(1944). "Alfonsa de la Torre. Égloga". Mediterráneo. Guion de Literatura (Universidad Literaria de Valencia) 7-8, 7 de agosto, 270.

TORRE, Alfonsa de la (1943a). Égloga. Prólogo de Josefina Romo. Madrid: Ed. Hispánica.

(1943b). "De los surcos se levanta". Revista Garcilaso 2, s.p.

(1944). Carolina Coronado poetisa romántica (Tesis doctoral inédita). Director Joaquín de Entrambasaguas. Universidad de Madrid.

(1948). Oda a la Reina del Irán. Madrid: Tall. Gama. (1950). Oratorio de San Bernardino. Madrid: Imp. Silverio Aguirre. [Reed. en Madrid: Torremozas, 2016 (con prólogo de Elena Medel).] (1960). Epitalamio a Fabiola. Madrid: Estades. (1969). Plazuela de las obediencias. Madrid: Imp. Aguirre. (1974). "Celdas para aparcar azucenas azules". En La vuelta y 19 cuentos más, Carlos Murciano et al., 121-138. Madrid: Confederación Española de Cajas de Ahorros. [Reed facsimilar. Estudio preliminar de María Payeras. Cuéllar: Ayuntamiento, 2010.] También en http:// www.cervantesvirtual.com/obra/celdas-para-aparcar-azucenasazules/ [01/03/2017].

(2011). Obra poética. Edición y estudio preliminar de María Payeras. Madrid: Eila Editores/Ayuntamiento de Cuéllar.

Recibido el 16 de marzo de 2017

Aceptado el 11 de abril de 2017 